\title{
The Belarusian Theatre Studio in Moscow: 1921-1926
}

\author{
Andriej Moskwin \\ Department of Central and East European Intercultural Studies, \\ University of Warsaw, Krakowskie Przedmieście 26/28, 00-927 Warszawa, Poland \\ Email: amoskwin@uw.edu.pl
}

\begin{abstract}
The subject of this study is the work of the Belarusian theatre studio in Moscow from 1921 to 1926. It traces the various periods of the studio's activities, the process of educational programme design, the attitude of students to study, and the attitude of the Belarusian authorities to the studio. The author had the opportunity to collect valuable material and reconstruct the work of the studio by virtue of the National Archives of the Republic of Belarus, the Academy of Sciences of Belarus, and the Belarusian State Archive-Museum of Literature archival materials, as well as memories of the artists themselves. The studio is the most important event in the history of Belarusian theatre: without the reconstruction of its activities, the picture of the work of the Yakub Kolas National Academic Drama Theatre in Vitebsk would be far from complete. Within five years, the studio raised actors and directors who later began their activities in Belarus. The programme proposed by the actors-pedagogues of the Moscow Art Theatre was innovative for them. An important part of the article is dedicated to Valentin Smyshlyaev, the director of the studio. It is worth remembering that there was no acting school in Belarus at the time and the first professional theatre was not opened until 1920.

KEYWORDS: Belarusian Theatre Studio, history of the Belarusian theatre, Moscow Art Theatre, Valentin Smyshlyaev, theatre education
\end{abstract}

At the time of the opening of the Minsk Proletarian Theatre in 1918, the Belarusian authorities planned to create an exemplary worker-peasant theatre in Moscow. The goals of this theatre were to popularize Belarusian culture both in the Russian capital and throughout the Russian Soviet Federative Socialist Republic (RSFSR). It was expected that the new theatre would be founded on the basis of the Belarusian drama studio that had already been working in Minsk throughout the year. The curriculum included a variety of disciplines such as Belarusian culture and dialectology, peculiarities of choral chants, and the theory of performing arts had been drawn up. ${ }^{1}$ However, due to the difficult political situation in the republic, this attempt to create such a theatre failed.

Headed by three mentors (Belarusian and Jewish mentors in drama and an independent mentor in opera), the "Opera and Drama studio" came into the world three years later, on 1 October 1921. The Belarusian State Theatre-1 (BST-1, Беларускі

1 1918. Аб патрэбе стварэння Студьі з беларускай мовай у Маскве, ААТІМЭФНАНРБ, воп. II, аАз. зах. 1, с. 2. 
Азяржаўны Тэатр-1 in Minsk, opened in 1920), with drama, opera, and ballet troupes, was a vivid example of the interaction of the dramatic and operatic staff. The studio was supposed to work at the Belarusian Academic National Theatre (BANT), which was organized earlier (on 1 August 1921). The official memo addressed to Anatoly Lunacharsky, the chairman of the RSFSR People's Commissariat of Education (PCE), had a note to the effect that the BANT should become the most important centre of theatrical and artistic activity aiming to organize an exemplary Belarusian theatre and to show the originality of Belarusian culture, the existence of which was stubbornly denied by native Russians. ${ }^{2}$ The studio's advertisement appeared on the pages of the Belarusian press, ${ }^{3}$ and the number of vacancies as well as the Regulations was approved. ${ }^{4}$ The choice of the location was determined by the fact that Moscow was a reference art-wise and the only place in the RSFSR where it was possible to study the world's artistic heritage. ${ }^{5}$

The newly-created Belarusian studio was supposed to serve two main functions: first, to be an educational centre and, second, to be an integral part of the future theatre. The studio participants were expected to master the basics of the acting profession quickly and to prepare stage performances that later should be shown in Minsk and on tours. Two years later, the studio was to be transformed into a full-fledged theatre, "in which the work shall be conducted more thoroughly and scrupulously". 6 A biannual organizational plan was approved. The training period was divided into four five-month stages.

Classes and workshops were to be conducted under the supervision of experienced tutors, whose work was meant to become an example for young students. On 22 November 1921, a list of ten tutors was approved: Alexei Bondarev ${ }^{7}$ (the artistic director of the Belarusian group), Alexander Chaban, Sofia Hyacinth, Boris Afonin, Artyom Sokolov (all from the Moscow Art Theatre), Rostislav Verkhulevsky (vocal studies), and Leo Steinberg (music studies). The classes in the history of Belarusian theatrewere taught by Zmitrok Biadulya, and Belarusian

2 1921. НАРБ: 32.

3 "From 1 September, BANT and two studios - drama and opera - will be opened in Moscow. The head of the drama studio will be the actor and one of the heads of the First Studio of the Moscow Art Theatre - Boris Shushkevich, and the opera - the composer A. Miklyaev. Each studio will consist of thirty students. Our newspaper will soon inform readers about the procedure and conditions of admission of the applicants from Belarus to the studio. BST-1 actor Ales Lyazhnevich (Incapable) and poet Mikhas Charot will be sent to Moscow together with the students". (Савецкал Беларусь 1921: 4).

4 Палажэньне аб...1976: 105.

5 1921. НАРБ: 22.

1921. НАРБ: 405.

7 Alexei Bondarev (1884-1939) was an actor at the Moscow Art Theatre from 1908. In 1922, he went on tour with the theatre and sought asylum in the United States. He worked in the Prague group of the Moscow Art Theatre, founded in 1922 by Maria Germanova. In 1923, he travelled around Europe with the theatre staff. He played in several films. From 1930, he lived in Paris and performed, including at the Mikhail Chekhov Theatre (1931). 
culture studies were led by Mikhas Charot. Each tutor of the studio gave threehour lessons twice a week. Ales Miklyaev became the headmaster of the studio, and Mikhail Rafalsky was his deputy. Classes were held in the premises of the First Studio of the Moscow Art Theatre.

The delayed entrance exam was held in Moscow on 12 November 1921. The academic year 1921/22 began on 15 November. The first Belarusian group included nine people: Konstantin Sannikov [Канстанцін Саннікаў], Alexander Ilyinsky [А^яксандр Іцьінскі], Irina Zhdanovich [Ірына ЖАановіч], Stefania Stanyuta [Стәфанія Станюта], Yanina Glyabovskaya [Яніна ГАябоўская], Anya Savich [Аня Савіч], Vera Krautsevich [Bepa Краўцэвіч], Tatiana Bondarchyk [Таццяна Бандарчык], and Olga Vashkevich [Вольга Вашкевіч]. As new candidates appeared, the number of students was increased to sixteen. Most of them (Sannikov, Stanyuta, Ilyinsky, Vashkevich, Glyabovskaya, and Bondarchyk) had already had some stage experience at the First Belarusian Theatre Company of Drama and Comedy (Першаe беларускае таварыства драмы і камедыі) and the BST-1, and some tried their hand in amateur acting groups.

From 15 November 1921, after the beginning of regular classes, studio management was facing serious organizational and artistic issues. First and foremost, Ales Miklyaev turned out to be a bad director: he paid too little attention to the organizational issues and was unable to solve students' major problems quickly and efficiently. Besides, he had a conflict with his deputy Rafalski. Proper organization of the learning process was also an urgent problem as cancellation of classes made it impossible to adhere to the plan. The students had to perform pieces of plays, interludes, or dedicated scenes in a cinema before the motion-picture show. However, the students believed that the work of the studio as an educational centre went against the objective tasks of the repertory theatre since the studio should later become the BANT. In the letter to the People's Commissariat of Education, they asked for the separation of the studio, paying attention to the fact that the existing theatre only misrepresented the reputation of the Belarusian people and theatrical art, which only recently had begun to revive and develop rapidly.

As a result, on 25 November 1921, the People's Commissariat of Education decided to close the BANT and reorganize the studio. The journalist and teacher Mikhas Gursky, who was one of the figures of the Belarusian Renaissance, became the new director. Three separate groups: Belarusian, Jewish, and operatic (the last one had never been opened) had their own directors. Ales Nekrashevich became the head of the organization of the educational process of the Belarusian group, while the Jewish group was headed by Mikhail Rafalsky, who also served as Deputy Director of the studio. The term of studies was extended from two to five years, and it was decided to adopt the programme of the State Institute of Theatre 
Arts. ${ }^{8}$ The studio came under the control of the BST-1. It was supposed that upon their return to Belarus, the studio's learners would present the repertoire they had prepared in Moscow.

After visiting of the first-year exams (8 June 1922), Mikhail Moroz, the Plenipotentiary Representative of the BSSR in the RSFSR, was pleased with the results of the work and expressed admiration for the dedicated, thorough, and honest attitude to the work of the teachers-actors, who put their strength, love, knowledge, and soul in the learning process. Moroz also noted the enthusiasm of the students that helped to establish a warm relationship between them and their teachers. ${ }^{9}$

Meanwhile, on 8 February 1922, the studio council decided to increase the number of students to twenty people. ${ }^{10}$ On 11 August 1923, the Commissariat passed another reform: the studio was given the status of a higher educational institution, the annual enrolment requirement, and an admission limit of ten students every year. The examinations were held in two stages: first in Minsk and then in Moscow. From 1921 to 1925, 200 enrolees signed up for entrance examinations (in 1921, 45 people signed up and 16 were accepted, in $1922-70$ and 15, in $1923-105$ and 18, in 1924 - about 130 and 12, and in 1925 ten signed up and two were accepted). The trial period lasted for one year. Some students left the studio due to health issues, some for financial or family reasons, and the others were forced to leave the studio due to the lack of talent and professionalism. After the end of the academic year $1921 / 1922$, the Belarusian group had ten students, in 1922/1923 there were 16 of them, in 1923/1924 - 26, in 1924/1925 - 32, and 1925/1926 - 34. Later, all these people became members of the BST-2 (Belarusian State Theatre-2) and were sent to Vitebsk. Studying in Moscow was an extremely important experience for Belarusian students, most of whom came from villages and small towns. Along with the prerogative of receiving professional education, they had the opportunity to get acquainted with the achievements of Russian culture and art, which, of course, positively affected their intellectual development and helped them to nurture personal views on art. Konstantin Sannikov noted that all studio learners without exception "kept an eager eye on Moscow's theatrical life, tried not to miss an exhibition, a literary debate, or a performance". "When we came there [to Moscow], of course, everyone absorbed [the culture] like a sponge", "to be inside it, to breathe with it every day and every night meant to receive a charge of great strength for life, to absorb the atmosphere that will stimulate all your abilities" ${ }^{12}$ Stefania Stanyuta remembered those times.

8 In 1921, the Russian University of Theatre Arts was renamed the State Institute of Musical Drama. As early as 1922, it changed its name to the State Institute of Theatre Arts (State Institute of Theatre Arts, GITIS). At that time, the school consisted of nine independent workshops, each headed by a master.

9 1922, НАРБ: 111.

10 1922. НАРБ: 24.

11 Саннікаў 2006: 18.

12 Станюта 1994: 35, 37. 
Konstantin Sannikov remembered two performances of the Moscow Art Theatre: Maeterlinck's Blue Bird and Gorky's The Lower Depths, ${ }^{13}$ which, he believed, greatly influenced his skills. Pavel Malchanau [Павел Маўчанаў] wrote: "Although initially somewhat hostile and cautious, we still watched these performances closely, and then we became more and more fascinated by them". ${ }^{14}$ The mastery of Meyerhold and Tairov greatly influenced Stanyuta. She watched each play staged by these directors several times. ${ }^{15}$ Fascinated by dance, Stanyuta could not miss the performances of Isadora Duncan and the ballets directed by Kasyan Galeizovsky and Nikolai Forager.

During the second year (16 October 1922 - 1 July 1923), Ales Lyazhnevich became the mentor of the Belarusian group, and the list of teachers was slightly reduced. In addition to the artistic director Alexei Bondarev, classes of scenic etudes were taught by Boris Afonin (First Studio of the Moscow Art Theatre), performing arts by Alexander Geirat (First Studio of the Moscow Art Theatre), psychotechnics by Valentin Smyshlyaev (Moscow Art Theatre), biomechanics by Irina Meyerhold (GITIS), declamation by Maria Uspenskaya (Moscow Art Theatre), and music theory by Vera Arenskaya-Zavadskaya (Third Studio of the Moscow Art Theatre). On 11 December 1922, a new four-part curriculum was approved. ${ }^{16}$ In the note of 11 May 1923 addressed to the PCE commissar Vsevolod Ignatovsky and in the report of 20 July 1923 on studio activities, it was noted that in the running academic year there were difficulties in organizing the normal course of classes due to staff reductions and a lack of a detailed curriculum and permanent enrolment of students from Belarus. Classes consisted of three blocks: (1) Stanislavsky's system (126 hours), (2) work on separate scenes and plays (227 hours), and (3) physical education (250 hours).

The studio had three venues at its disposal: the "Uranus" cinema (19 Sretenka Street), the "Ars" cinema on the Arbat (51 Plotnikov Lane), and rooms on 6 Maly Kislovsky Lane. It happened that the dormitory (Red Square 2), the building of the Representation of Belarus in the RSFSR, and even Valentin Smyshlyaev's apartment were used as well. Theoretical classes were held during the daytime, while pieces of training and individual workshops in the evening. Tatiana Bondarchyk said: "We went to the libraries, searched for material, made notes. Everyone had to bring their "continuation" to the next classes. We read, argued, made etudes". ${ }^{17}$

Concerned by the situation, Mikhail Moroz, the Plenipotentiary Representative of the BSSR in the RSFSR, and Mikhas Loika, the representative of the BSSR PCE in the RSFSR, wrote in a report addressed to Ignatovsky, the commissar of the PCE

\footnotetext{
13 Саннікаў 2006: 17-18.

14 Малчанаў 1984: 37.

15 Станюта 1994: 34.

16 1922. НАРБ: 172.

17 Бандарчык 1966: 3.
} 
BSSR, on 11 May 1923: "It is necessary to find a new director for the studio, who would have proper authority and would be able to concentrate the most remarkable artistic forces of Moscow around himself, to give the studio a proper artistic direction. $<\ldots>$ The studio has a very strong and capable core of teachers who are artists of the First Studio of the Moscow Art Theatre, and, what is more important, like-minded people art-wise who work together on the proper forward development of the Belarusian theatre". ${ }^{18}$ The note also emphasised that the need to find such an artistic director had become an urgent matter for the studio since the students had already formed a group that is ready to stage full-fledged art performances.

As a result of these measures, a meeting of the studio council, attended by the artistic director of the BST-1 Evstignei Mirovich, was held on 21 May 1923. The studio was reorganized. Valentin Smyshlyaev was elected the director of the studio and Alexander Geirat was elected his deputy. ${ }^{19}$ It was stated in the protocol that Smyshlyaev had recognition and authority among both teachers and students and that he would be responsible for all the creative activities of the studio. ${ }^{20}$ In addition, the studio gained full independence, which was approved in the decree. ${ }^{21}$

In an article for the Maladnyak ("The Youth") magazine (1924), Mikalai Mickiеwicz [Мікалай Міцкевіч], a learner of the studio, presented Smyshlyaev as "a fresh new force, brilliant in his talent and knowledge".22 According to him, from the new teacher, the students received "answers to all our questions about art, about theatre in general, and about the new theatre, about the connection of art with social and natural phenomena".3 "Of average height, thin, extremely lively, temperamental, and emotional. <...> He was awaited and feared a little: where else will he "push" us, and in which direction?.. All the time he excited our imagination," ${ }^{24}$ Tatiana Bondarchyk thus remembered Smyshlyaev for the rest of her life.

Along with directing, pedagogy was an important area of Smyshlyaev's activity. As contemporaries noticed, Smyshlyaev was a teacher "by the grace of God"; he could easily discover and develop the acting abilities of his students. His education, openness, and ability to work in a team led to him being the only actor of the Moscow Art Theatre- 2 to be invited to work in different theatre studios and groups. Smyshlyaev started working in the Belarusian studio in 1922. Stefania Stanyuta remembers that at that time Smyshlyaev was a fan of synthetic theatre. "A man, a true creator, who wanted - and discovered - something new in classic things, though it seemed

18 1923. НАРБ: 85.

19 Alexander Geirat (1882-1947), an actor of the "Ancient Theatre" (1911-1912, St. Petersburg), Moscow Art Theatre (1913-1923, 1935-1947), and Moscow Art Theatre-2 (1924-1935).

20 1923. НАРБ: 175.

21 Ibidem.

22 Міцкевіч 1924: 104

23 Ibidem.

24 Бандарчык 1966: 3. 
that everything had already been discovered", 25 Stanyuta wrote later. "Smyshlyaev had neither delusions of grandeur nor conceit. He never claimed to be a leader. $\mathrm{He}$ inspired others with his rich imagination and pointed the potential of students in a direction that, in his opinion, deserved attention and creativity" ${ }^{26}$ said Smyshlyaev's colleagues at Proletcult. ${ }^{27}$

For Smyshlyaev, the Belarusian studio was like a laboratory where he compared his theoretical approaches with the views and skills of the students and conducted polemics. It was here that he tested the validity of his groundbreaking stage directorial concepts. Undoubtedly, the contact with the students and his status as a teacher helped him greatly in formulating his own ideas and concepts of theatrical art in the broad sense of the term.

After Smyshlyaev took over the position of the artistic director of the studio, increasing guardianship and at the same time tighter control of this organization by the Belarusian authorities could be observed. The Belarusian authorities regularly visited the Studio to meet the students. The day after the meeting of the Art Council, Moroz expressed satisfaction with the choice of the artistic director in a letter to the PCE chairman Ignatovsky. He insisted that Smyshlyaev's participation in the life of the studio was indispensable. Moroz emphasized that teachers were working with interest and dedication: they were good tutors, professionals, and, most importantly, they loved the Belarusian language and literature, the soul of Belarusians, got along well with students, and desired to take the students to graduation. At the same time he pointed at a number of problems (the Regulations adopted in 1921 had become obsolete; the Art Council was malfunctioning; "some students show excellent results in profile subjects, and their ideological results are poor"; "students eat irregularly and poorly, have no money to buy shoes and clothes, and they often get sick as a result"; "students live in cramped conditions and there was not enough permanent space for classes" $\left.{ }^{28}\right)$.

At the end of 1923 (20 December), Moroz once again sent a letter to the PCE chairman Ignatovsky, in which he paid attention to two other issues, first of all to the ineffectiveness of the studio director Ales Lyazhnevich. According to Moroz, the studio was in some sort of immobility, waiting for a proper shift. Moroz thought that these changes should take place as soon as possible since dissatisfaction was beginning to prevail among the students as they were losing faith in themselves and their abilities: "The head of the studio is needed tomorrow". In his opinion, Evstignei Mirovich,

25 Станюта 1993: 216, 220.

26 Никитин 1996: 156.

27 Proletkult (Rus., proletarskaya kultura, "proletarian culture") - was an experimental Soviet artistic institution that arose in conjunction with the Russian Revolution of 1917 and existed until 1932. It aspired to radically modify the existing artistic forms by creating a new, revolutionary working-class aesthetics, which drew its inspiration from the construction of modern industrial society in backward, agrarian Russia.

28 1923. HAPБ: 92-93. 
the artistic director of the BST-1, could be such a person. In its turn, the second issue noticed by Moroz was the introduction of an additional position, that of "a Belarusian ideologist" ("He is needed to help training the artists who sincerely love Belarus and its culture"29).

At the beginning of 1924 (20 January - 6 February), the PCE inspector Ales Nekrashevich visited the studio. In his report, he drew attention to several issues: the lack of a set schedule ("there are some days with only one lecture, while there are days with eight ones"), the lack of permanent space for classes, and insufficient independence of students' work ("Students live only by what they learn at lectures. And most of their spare time is dedicated to wild games, doing nothing, or completely vicious pastimes" ${ }^{30}$ ).

At the end of the 1923/1924 academic year, Moroz convened a commission, whose purpose was a comprehensive study of the situation in the studio. The "Belarusian spirit" tuition and patriotic upbringing, the focus on "Belarusianness" were the two most important points noted in the report of the commission (15 April 1924). The document also noted that all classes were held only in Russian, while the Belarusian language was taught only for two hours once a week. Too little time was also dedicated to the "Political Grammar" studies (only two hours per week). The Commission affirmed that this subject should be primarily important for the students. The report conclusions emphasized that (a) by the following year it was necessary to strengthen the students of the studio with citizens of working and peasant origin (at the moment of the report, there were 32 citizens: four of the working-class origin, seven of a peasant, and 21 of other) and (b) it was necessary to increase the number of hours dedicated to the subjects of "Belarusian studies" (the programme should include the history, geography, and literature of Belarus) in the curriculum. ${ }^{31}$

This document was the basis for the evaluation of the studio's activities by the Central Committee of the Belarusian Art Workers' Association (Таварыства працаўнікоў беларускага мастацтва) on 28 June 1924. In particular, it pointed out that students do not form "communities", and Lyazhnevich gathered only the best-educated and intelligent students around him. "It is necessary to make a selection of the students since ideologically unfamiliar people had joined the studio. Little attention is paid to general subjects and political disciplines" ${ }^{\prime 2}$.

The following was decided in the resolution of 30 June 1924: "(1) to characterize Lyazhnevich's work as unsatisfactory; (2) to cleanse the studio on the basis of the social status and academic results; (3) to give the studio complete artistic freedom that should be based on national and cultural features". ${ }^{33}$ 
It should be borne in mind that at the time of the opening of the studio in Moscow, the PCE of the BSSR had neither a clear and well-defined concept on this issue nor a corresponding training programme for the professional Belarusian theatre. The Commissariat was unable to predict the difficulties it would face in organizing such an important matter. On the one hand, the presence of the elements of Belarusian culture and traditions in the programme was accentuated, while, on the other hand, there was also talk about adapting the achievements of Russian culture. For example, in the 1918 programme of the studio, the main accent was placed on "Belarusianness". Such disciplines as "Belarusian music, song, and choral chants", "Belarusian folk dances and motion", "Belarusian dialects and pronunciation" were dominating. Only two subjects concerned theatrical art directly: "Scenic practice and improvisation" and "Theory of theatrical art with to the focus on the tasks of the Belarusian theatre". ${ }^{34}$ The Belarusian Art Workers' Association noted in one of the protocols (28 June 1924) that the studio should rely primarily on the "national and cultural specifics of Belarus" in its activities and in choosing the repertoire. In one of his letters to the PCE chairman Ignatovsky (2 June 1923) Moroz offered Smyshlyaev a work-related visit to Belarus to become acquainted with the Belarusian village and its life, with the aim of applying the experience gained there in forming the repertoire and interpreting the material. ${ }^{35}$

A number of other documents focused on the connection between Belarusian and Russian cultures. For example, in 1921, when explaining the opening of the studio in Moscow, the PCE emphasized the fact that this institution was charged with the task of "mastering and future use of the experience and achievements of the Russian theatre school". ${ }^{36}$ It should be remembered that the tutors of the studio were not acquainted with Belarusian history, culture, and literature, and classes were held in Russian. Subjects related to the Belarusian language and literature occupied a very insignificant place in the curriculum. The students were the victims of such a policy. It is no coincidence that Mikalai Mickiewicz tried to point out the primacy of the creative component over the ideological one in one of his articles: "Who can say: 'Belarusian theatre must be like this'?! Who will show the real path of the Belarusian theatre without a mistake?! $<\ldots>$ The identity of the Belarusian theatre is one of the most important tasks of its existence and value. But all these issues, quests, and achievements can only be fulfilled when there is a core of relevant, highly-cultured Belarusian theatrical artists. So far they are not such, but I believe they will be such. $<\ldots>$ We want to be artists. We want to find a path for the Belarusian theatre and follow it. We want to be up to date. And as young people, we are supposed to do that, and we do care about that". ${ }^{37}$

34 1918. НАРБ: 49 (it was noted that of the 1,025 hours per year, only 250 were allocated to these two subjects).

35 1923. НАРБ: 92.

36 1921. НАРБ: 132.

37 Міцкевіч 1924: 106. 
Fully aware of the importance of his responsibilities and the existing problems, Valentin Smyshlyaev started his work with great enthusiasm: on 1 December 1923, he approved the list of tutors and developed a plan for the 1923/1924 and the following academic years. At the studio's board meeting on 12 November $1923,{ }^{38}$ the issue of improving the living conditions of students was discussed and soon this problem was solved: the studio received rooms near the "Ars" cinema for its classes. In addition, Smyshlyaev appealed to the PCE of the BSSR for an increase in the number of tutors and eventually received a positive response. In a statement addressed to the Central Executive Committee of the BSSR, the Academic Centre asked to approve 45 staff positions. It was thanks to Smyshlyaev's efforts that new Regulations ${ }^{39}$ were approved on 27 March 1924, which granted the studio the status of a higher educational institution (Belarusian State Theatre Academy), and the end of the classes was planned for the spring of 1926. This document also defined the duties of the director and the functioning principles for the Directorate, the Art Council, and the subject commissions. It should be noted that the Regulations touched upon the issue of student participation in the Art Council: students were to make up one-third of the members of the council. The studio consisted of three groups: junior, secondary, and senior. The head of the senior group was Valentin Smyshlyaev, Boris Afonin was the head of the secondary group, and Victor Gromov, an actor of the First Studio of the Moscow Art Theatre, headed the junior group.

In addition, a director's group was created on the initiative of Smyshlyaev in the 1924/1925 academic year. It included the most talented students: first Konstantin Sannikov, Timofey Sergeychik [Цімафей Сяргейчык], Mikalai Mickiewicz, and later Alexander Ilyinsky, Tatiana Bondarchyk, Vasily Rogovenko [Васімь Рагавенка], Joseph Tchaikovsky [Язэп Чайкоўскі], Stepan Stelmakh [Сцяпан Стэмьмах], and Lyubov Mazalevskaya [

This was in line with the PCE's plan to use the studio to train future singers, set designers, and playwrights. Mikalai Mickiewicz confirmed this on the pages of the Maladnyak (The Youth): "We want our own directors, artists, writers, composers to stand out from our team ... I think it can be done, but more work needs to be done than it seems". ${ }^{40}$

Thanks to this programme, students gained a thorough knowledge of the history of Russian and Western European theatre, learned the secrets of acting (primarily the system of Stanislavsky) and stage directing, the basics of music, and singing. At the same time, there were classes for which the students prepared etudes from plays. Particular emphasis was placed on physical development: students had to control their bodies perfectly and be able to play in mass scenes. It is no coincidence that 
acrobatics, "harmonic gymnastics", the method of Michael Foregher and Émile Jaques-Dalcroze occupied an important place in the programme. Much of the programme was worked out and used by Smyshlyaev in his previous practice. ${ }^{41}$

Music classes led by Gregory Schneerson, ${ }^{42}$ a graduate of the St. Petersburg Conservatory, usually ended with a small concert, during which the teacher, who was an outstanding pianist, performed pieces by Beethoven, Liszt, Chopin, or Tchaikovsky. In her turn, Irma Yauzen, ${ }^{43}$ invited from Minsk, revealed the secrets of folk singing to the students. Timofey Sergeychik remembered the classes held by Viktor Gromov, who taught Stanislavsky’s system: "Each of his lessons was a great revelation to me. Fascinated by the exercises of the system, we transferred our sketches to the street, checking the truth of the performance and the strength of the impact on people". ${ }^{44}$

Stefania Stanyuta remembered that some teachers had their "favourites". For instance, Lyudmila Alekseyeva, the teacher of scenic motion, paid special attention to Stanyuta, Alexander Ilyinsky, and Konstantin Sannikov. She invited the three of them to her home and to her private studio for individual lessons. Several times she asked them to perform as "living sculptures" in front of the actors of the Moscow Art Theatre-2 during the classes on the history of ancient Greek theatre. They had to enact episodes depicted on antique vases. The scenic motion classes were often accompanied by live music. ${ }^{45}$

Stanyuta praised the role of Smyshlyaev in the process of acting education: "He sought to combine the characteristic and the sharpened form with the depth of the content, and at the same time he trusted the expressiveness of the physicality, which is as charged and intense as the inner world of the human. $<\ldots>$ He tried to awaken and push our imagination, our ability to improvise and the perception of music". ${ }^{46}$ Smyshlyaev wanted the students of the studio to create an emotionally harmonious team "of one blood-type". At one of the classes he said: "Each of you is valuable in this team, outside of it you will still be something of yourself. Living and enjoying what you've got for a year or two, but then lose everything". ${ }^{47}$ Smyshlyaev liked to repeat that actor should be an example to others in everything, to be modest in life: so that neither behaviour nor clothing is obvious. ${ }^{48}$

\footnotetext{
41 Смышияев 1920.

42 Gregory Schneerson (1901-1982) - the musicologist, the author of numerous works, including Современная американская музыка (Contemporary American Music; Moscow, 1945), Современная английская музыка (Contemporary English Music; Moscow, 1945), Французская музыка 20 века (French Music of the Twentieth Century; Moscow, 1964), Портреты американских композиторов (Portraits of American Composers; Moscow, 1977).

43 Irma Yauzen (1897-1975) - a singer and performer of folk music.

44 Сяргейчык 1973: 99.

45 Станюта 1994: 38.

46 Ibidem: 42.42.

47 Бандарчык 1924-1925: 2. 2.

48 Бандарчык 1996: 3.
} 
As a tutor, Smyshlyaev enjoyed great recognition and authority among the students. For many of them, he was a role model and example. He said during the classes: "The human soul always leans towards a true Artist. And the latter always suffers from the question: 'What does my art matter?' The artist must give his work freedom of perception. From here there should never be agitation art since it does not liberate but enslaves. Art used for propaganda purposes will never be alive, it is doomed to death, it is a declining art" ${ }^{49}$

Valentin Smyshlyaev directed five productions within two years: "Tsar Maximilian" and "Underworld" by Vasily Shashalevich [Васімь Шашалевіч], Shakespeare's A Midsummer Night's Dream, Bacchantes by Euripides, and "Eros and Psyche" by Jerzy Żuławski. In conceiving this plan, he was guided by his own taste and, in addition, contributed to the repertoire in the format of the capital's theatre, with the aim to attract intelligent and art-sensitive people. It should be remembered that at that time no decision had been made to dispatch the young troupe to Vitebsk. ${ }^{50}$

Received 15 May 2020

Accepted 29 May 2020

\section{References}

1. Бандарчык, Т. На пермай вярсие... [On the first verst...], Мітаратура і мастацтва, 29.11.1966. 96: 3.

2. Бандарчык, Т. На першай вярсце... [On the first verst...]. Мітаратура і мастацтва, 2.12.1966. 97: 3.

3. Малчанаў, П. Тэатр - жыщцё маё [Theater is My Life]. Мінск: Мастацкая мітаратура, 1984.

4. Міцкевіч, М. Беларуская студыя ў Маскве [The Belarusian studio in Moscow]. Maлadняк 1924. 5: 104-105.

5. Никитин, А. Московский дебют Сергея Эйзенитейна (1920-1921) [Moscow debut of Sergei Eisenstein (1920-1921)]. Москва: Интерграф Сервис, 1996.

6. Палажэньне аб Беларускай акадэмічнай оперна-драматычнай студы БАНТ тэатру [Regulations on the Belarusian Academic Opera and Drama Studio of the BANT Theatre], in: Мастацтва Савецқай Беларусі. Зборнік дакументау і матэрыялау у двух тамах, т. 1: 1917-1941, рэл. В. Бандарчык, Мінск: Навука і тэхніка, 1976: 105 .

7. Саннікаў, K. Незабъцунае [Unforgettable]. Театр Константина Санникова. Избранные статьи и воспоминания. Минск: Тонпик, 2006: 17-18.

8. Станюта, А. Мираж (Стефания) [Mirage (Stephanie)]. Аружба народов, 1993. 9: 210-220.

9. Станюта, А. Стэфанія [Stephanie]. Мінск: Бемарусь МП „Аўрыка”, 1994.

10. Сяргейчык, Ц. Нататкі акцёра: шлях жыция і твориасиі [An Actor's Notes: The Path of Life and Creativity]. Мінск: Мастацкая мітаратура, 1973.

11. Тэатр [Theatre], Савецкая Бемарусь 20.07.1921. 157: 4.

12. Тэатр [Theatre], Савецкая Беларусь 20.07.1923. 173: 4.

13. Moskwin, A. Teatr biatoruski 1920-1930. Odrodzenie i zagtada [Belarussian Theatre: 1920-1930. Rebirth and extermination]. Warszawa: BEL Studio 2014: 129-323.

49 Бандарчык 1924-1925: 14.

50 Moskwin 2014: 129-323. 


\section{Archival documents}

1. 1918. Аб патрэбе стварэння Студыі з беларускай мовай у Маскве [About the need to open a studio with the Belarusian language in Moscow], ААТІМЭФНАНРБ. F. II. B. 1. L. 2.

2. 1924-1925. Бандарчык, Т. Канспекты мекцый В. Смышляева (1924-1925) [Abstracts of V. Smyshlyaev's lectures (1924-1925)]. БА АМАіМ. F. 23/1. B. 4. L. 14.

3. 1924-1925. Бандарчык, Т. Канспекты мекцый В. Смышляева (1924-1925) [Abstracts of V. Smyshlyaev’s lectures (1924-1925)]. БА АМАіМ. F. 23/1. B. 25. L. 2.

4. 1921. Запіска ў справе акадэмічнага каштарысу оперна-драматычнай Студыі (1.08.-31.12.1921) [A note in the case of the academic assessment of the Opera and Drama Studio]. НАРБ. F. 93/1. B. 222. L. 405.

5. 1922. Аіст Паўнамоцнага Прадстаўніка Беларусі ў РСФСР М. Мароза ў Акадэмічны цэнтр НКА [Letter of the Plenipotentiary Representative of Belarus to the RSFSR M. Moroz to the Academic Centre of the PCE]. НАРБ. F. 42/1. B. 524. L. 111.

6. 1922. НАРБ. F. 42/1. B. 524. L. 22, 235, 236, 250-254, 264.

7. 1923. НАРБ. F. 42/1. B. 537. L. 17, 85, 92-93, 175, 184.

8. 1918. НАРБ. F. 804/1. B. 23. L. 49.

9. 1921. Положение о студии Белорусского Государственного Академического театра [Regulations of the Studio of the Belarusian State Academic Theatre]. НАРБ. F. 42/1. B. 537. L. 132.

10. 1922. Пратакол пасяджэньня Студыі БАНТ [Protocol of the meeting of the BANT Studio]. НАРБ. F. 42/1. B. 524. L. 24.

11. 1921. Службовая запіска прадстаўніка БССР у РСФСР у НКА на імя таварыша А. Ауначарскага [Official note of the representative of the BSSR in the RSFSR to the PCE addressed to A. Lunacharsky]. НАРБ. F. 15/1. B. 11a. L. 32.

\section{Andrej Moskvin}

\section{Baltarusių teatro studijos veikla Maskvoje: 1921-1926 m.}

\section{Santrauka}

Tyrimo tema - baltarusių teatro studijos veikla Maskvoje 1921-1926 metais. Straipsnyje aptariami skirtingi studijos veiklos etapai, teatro mokomosios programos kūrimo procesas, studentų ir Baltarusijos valdžios požiūriai ị studiją. Studijos veiklos rekonstrukcija atlikta remiantis Nacionaliniame Baltarusijos respublikos archyve, Baltarusijos mokslų akademijoje ir Valstybiniame Baltarusijos literatūros archyve-muziejuje saugoma medžiaga, taip pat pačių menininkų prisiminimais. Ši studija - pati svarbiausia Baltarusijos teatro istorijoje, be jos būtų neįmanoma kalbèti apie Nacionalinio akademinio Jakubo Kolaso dramos teatro Vitebske istoriją. Maskvos dailès teatro aktoriai ir pedagogai tuometiniams studentams pasiūlè novatorišką programą. Nemaža dalis straipsnio skirta studijos režisieriui Valentinui Smyšlajevui. Studijos išugdyti aktoriai ir režisieriai véliau pradejo dirbti Baltarusijoje. Verta paminèti, kad tuo metu Baltarusijoje nebuvo vaidybos mokyklos, o pirmasis profesionalus teatras savo veiklą pradèjo 1920 metais.

RAKTAŽODŽIAI: baltarusių studija, baltarusių teatro istorija, Maskvos dailès teatras, Valentin Smyšlajev, teatro mokymas 